\title{
Solar Oven Manufactured from a EPS Thermal Box
}

\author{
Luiz Guilherme Meira Souza, Luiz Guilherme Vieira Meira de Souza, Jailton Weber Gomes, Carlos \\ Roberto Rocha da Silva, Natanaeyfle Randemberg Gomes dos Santos, and Larissa Caroline Fernandes \\ Costa
}

\begin{abstract}
It presents a solar oven for baking food, manufactured from a thermal box of EPS. The solar oven proposed is a prototype of solar concentration for the operation of baking foods such as breads, cakes, pizza among others. The main innovation of the work is the use of EPS cooler, widely available, low cost and with a structure already defined and manufactured, avoiding the production of mold to get the box. The inside of the box EPS enclosure baking oven, was coated on the bottom and side sheets by mirrors forming the profile which gives the greater concentration of solar radiation. Above the floor of the oven is system with plane mirror reflector, which moves according to the movement of the sun, directing the solar rays into the oven where the food displaced into the baking. Are presented results of tests that diagnose the viability of using the solar oven for several types of food. Compared are the times of baking food with those obtained for other types of solar ovens presented by solar literature, also as compared to gas conventional oven. Preliminary tests have shown the feasibility of using such solar oven, temperature levels being achieved adequate for the purpose proposed, affording the baking of various foods. The tests show that the solar oven reached the maximum temperature of $123.8^{\circ} \mathrm{C}$ and baking various foods such as pizza, lasagna, cake, bun, and other in an average time 50 minutes. Proved the feasibility of use of the oven proposed.
\end{abstract}

Index Terms - Solar, solar oven, EPS box, baking food, low cost.

\section{INTRODUCTION}

The firewood is probably the oldest energy used by man and still has great Importance in the Brazilian energy matrix, participating with about $10 \%$ of primary energy production [1].

About $40 \%$ of wood produced in Brazil is transformed into charcoal. The residential sector is the most expensive wood (29\%). Usually it is for cooking food in rural areas. A family of eight requires approximately $2.0 \mathrm{~m}^{3}$ of wood per month to prepare their meals. The Industrial sector comes next with about $23 \%$ of consumption. The main industries that consume fuel in the country are food and beverages, ceramics and pulp and paper [2], [3].

These data show the that massive use of wood, putting at risk the health of the planet, point to the need for a policy of mass use of solar cooker for cooking food as a way to preserve nature and Also to lessen the ecological imbalance the indiscriminate use of firewood, while Minimizing the emission of polluting gases into the atmosphere [4].

The use of solar energy for cooking and baking food is

Manuscript received July 21, 2015; revised October 28, 2015.

The authors are with the UFRN - Universidade Federal do Rio Grande do Norte, Campus Universitário Lagoa Nova, CEP 59078-970, Natal/RN Brasil (e-mail: lguilherme@dem.ufrn.br). one of the oldest and spread this energy source and its main characteristic its social function [5]. It's wonderful to see that people in Africa use solar ovens and massively contributing to a policy of non-use of wood, which Contributes to the environmental imbalance of our planet [1], [6].

In the northeastern hinterland plagued by Droughts, the hinterland suffers from hunger and thirst due to inclement sunshine on their barren lands. The use of solar ovens in the solar scrub promises to reverse or at least mitigate this situation by allowing backcountry better living conditions [7], [8].

It presents a solar oven for baking food, manufactured from a thermal box of EPS for the operation of baking foods such as breads, cakes, pizza among others. Are presented results of tests that diagnose the viability of using the solar oven for several types of food.

The solar cooking food is one of the main research lines of the LMHES UFRN, having been the subject of numerous scientific papers published in various national and international conferences and eight Masters Dissertations.

\section{Materials AND Methods}

The solar oven made from a scrap box EPS presented the following dimensions: - external - Length: $0.74 \mathrm{~m}$, width $0.56 \mathrm{~m}$ and height: $0.20 \mathrm{~m}$; - internal - length: $0.625 \mathrm{~m}$, width: $0,44 \mathrm{~m}$. The internal area corresponded to $0.28 \mathrm{~m}^{2}$. The area of the reflecting surface that lines the inner walls of the furnace corresponded to $0.36 \mathrm{~m}^{2}$. The outer reflective surface presented a catchments area of solar radiation corresponding to $0.18 \mathrm{~m}^{2}$. Fig. 1 shows a schematic drawing of the solar oven, its components and their dimensions.

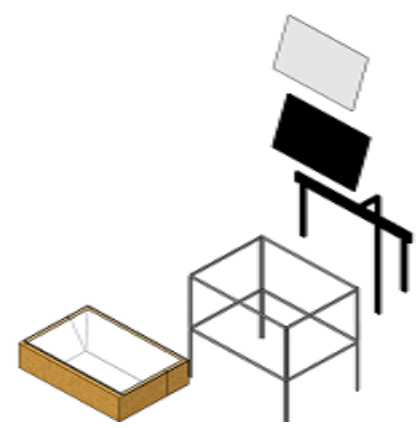

Fig. 1. Schematic drawing of the solar oven, its components.

The enclosure of the oven was covered with a transparent flat glass of three mm thick. The glass is seated in the box and EPS moves to facilitate loading and unloading of food offered for cooking. The furnace structure was fabricated using angles and provides rotational movement to facilitate the handling of the oven. 
Tests were performed without load for determining the temperature of the furnace box type solar studied. Temperatures were measured every five minutes. The tests were conducted for the period from 10:00 to 14:00 hours.

Tests were also performed to load the two baking pizza $400 \mathrm{~g}$, breaded chicken and $500 \mathrm{~g}$ of a cake $700 \mathrm{~g}$, determining the time required for this purpose. The same parameters were measured test without load for the same time interval. Were also measured temperatures inside the oven for evaluating the temperature difference between the base where is the food and the air around it. The temperatures of the internal air and base were measured with Chromel-alumel thermocouple Type $\mathrm{K}$ coupled to a digital thermometer.

The temperature data were measured with Chromelalumel thermocouples, connected to a digital thermometer MINIPA MT-914 with read range from $-70^{\circ} \mathrm{C}$ to $1200^{\circ} \mathrm{C}$ within $0,1^{\circ} \mathrm{C}$ and a maximum error in about $2.0 \%$. The global solar radiation was measured by a solar station installed in LMHES UFRN. Fig. 2 shows the solar oven in test.

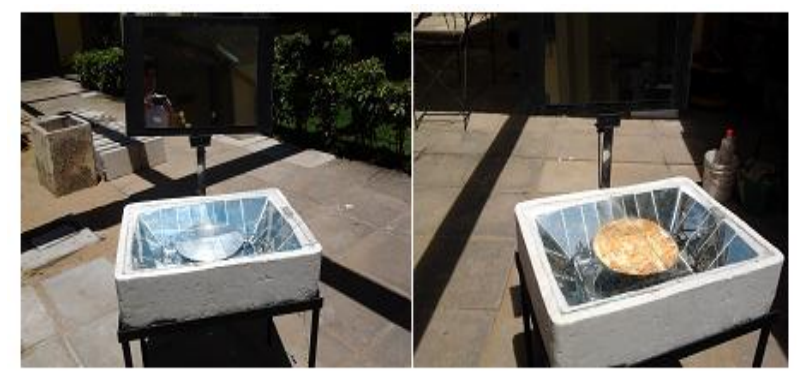

Fig. 2. Solar oven proposed in test in solar energy laboratory UFRN.

\section{A. Thermal Balance of Solar Oven}

The solar radiation incident enters in the solar oven in two ways: as global solar radiation incident on the glass cover and direct solar radiation reflected by the external mirrors. Much solar radiation as the direct solar radiation reflected by the mirrors external focus on the top of absorber shape and surface mirrored inside the oven. The energy balance equations are presented below.

\section{B. The Energy that Enters the Solar Oven (EEF)}

The energy entering the solar oven in two forms: the solar radiation incident on the roof solar oven and solar radiation directly reflected in the outside mirrors located on top of the solar oven. Equation 1 shows the total energy entering the solar oven.

$$
E_{e f}=E_{g}+E_{r e}
$$

$E_{e f}=$ Energy that enters the solar oven $(\mathrm{W}) ; E_{g}=$ energy from the solar radiation that falls directly on the solar oven $(W)$; = Energy of reflection of the mirrors of the upper solar oven $(W)$.

To calculate the energy input in the solar oven using the equations 2 and 3 shown below.

$$
\begin{gathered}
E_{g}=I_{g} \cdot \tau_{v} \cdot A_{v} \\
E_{r e}=I_{d} \cdot \rho_{e} \cdot \tau_{v} \cdot A_{v}
\end{gathered}
$$

$I_{g}=$ instantaneous global radiation entering the solar oven $=1000 \mathrm{~W} / \mathrm{m}^{2} ; I_{d}=$ instant direct radiation entering the solar oven $=800 \mathrm{~W} / \mathrm{m}^{2} ; \rho_{e}=$ mirror reflectivity $=0.95, \tau_{v}=$ glass transmissivity $=0,85 ; A_{v}=$ glass area $=00.28 \mathrm{~m}^{2}$.

\section{1) Energy lost by the side, bottom and the cover glass} $(E P F)$

Considering the average temperature of the oven external surfaces was calculated convective heat loss from such surfaces and the ambient air. Ignored for radiation emitted to the external environment due to the low temperature gradient between the exchange surfaces. To calculate the convective exchange, used the equation 4 . They performed several measurements in the temperature of the external surfaces for the period of highest incidence of solar radiation between 11 and 12 hours.

$$
E_{p_{f}}=Q_{\text {convec }}=h_{c} \cdot A_{s e} \cdot\left(T_{s}-T_{a m b}\right)
$$

$E_{P F}=$ Energy lost by the solar oven (W) $h_{c}=$ transfer convective coefficient between the outer surfaces of the oven and air $(\mathrm{W} / \mathrm{m} . \mathrm{K}) ; A_{s e}=$ area of the external surface of the oven temperature $\left(\mathrm{m}^{2}\right) ; T_{s e}=$ external surface of the solar oven $\left({ }^{\circ} \mathrm{C}\right) ; T_{a m b}=$ ambient temperature $\left({ }^{\circ} \mathrm{C}\right)$.

\section{2) Internal efficiency solar oven (IIF)}

The internal efficiency solar oven will be calculated by the ratio between the energy absorbed and available inside the oven and the total energy entering the solar oven by equation 5 .

$$
\eta_{i f}=\left(E_{a b s} / E_{e f}\right)
$$

Being:

$\eta_{i f}=$ internal efficiency of solar oven $(\%) ; E_{e f}=$ Energy that enters the solar oven (W); $\mathrm{E}_{\mathrm{abs}}=$ Energy absorbed by the oven $(\mathrm{W})$.

\section{ANALYSIS OF RESULTS}

Table I present the energetic contributions involved in the energy balance of the solar oven studied, and its thermal efficiency.

TABLE I: ENERGIES INVOLVED IN THE ENERGY BALANCE OF THE SOLAR

\begin{tabular}{lc}
\multicolumn{2}{c}{ OVEN STUDIED } \\
\hline \multicolumn{2}{c}{ ENERGY } \\
\hline Energy entering the furnace & 418,9 \\
Energy absorbed by solar oven & 326,3 \\
Energy lost by the solar oven & 92,6 \\
Internal Efficiency oven & $77,9 \%$ \\
\hline
\end{tabular}

The efficiency of the solar oven studied was around $78 \%$, since the energy lost corresponded to $22 \%$ of the energy that went into the baking enclosure of the oven. This efficiency demonstrates the wide feasibility study thermal solar oven, which resulted in the good efficiency of the insulation used. Subsequently, baking times proved also good thermal efficiency of the solar oven studied.

Table II shows the average results of the test evaluated the absorber temperature and the internal environment of the oven solar studied. The solar oven was placed on exposure 
to the sun 10:20 am. The average ambient temperature was $29^{\circ} \mathrm{C}$ and thermal sensation of $33^{\circ} \mathrm{C}$ during the test.

TABLE II: HOURLy AVERAGE RESUltS OF THE TEST WITHOUT LOAD

\begin{tabular}{ccccc}
\hline $\begin{array}{c}\text { Time } \\
\text { (hour) }\end{array}$ & $\begin{array}{c}T_{\text {absorber }} \\
\left({ }^{\circ} \mathrm{C}\right)\end{array}$ & $\begin{array}{c}T_{\text {internal }} \\
\left({ }^{\circ} \mathrm{C}\right)\end{array}$ & $\begin{array}{c}I_{g} \\
\left(\mathrm{~W} / \mathrm{m}^{2}\right)\end{array}$ & $\begin{array}{c}I_{d} \\
\left(\mathrm{~W} / \mathrm{m}^{2}\right)\end{array}$ \\
\hline $10: 30$ & 80 & 80 & 948 & 758,4 \\
$10: 40$ & 90 & 90 & 955 & 764 \\
$10: 50$ & 102 & 92 & 970 & 776 \\
$11: 00$ & 107 & 98 & 980 & 784 \\
$11: 10$ & 114 & 105 & 980 & 784 \\
\hline AVERAGE & 98,6 & 93 & 966,6 & 773,3 \\
\hline
\end{tabular}

TABLE III: RESUltS OF THE MEASURED PARAMETERS IN THE TEST TO BAKE A CAKE

\begin{tabular}{ccccc}
\hline $\begin{array}{c}\text { Time } \\
\text { (hour) }\end{array}$ & $\begin{array}{c}T_{\text {absorber }}\left({ }^{\circ} \mathrm{C}\right) \\
11: 15\end{array}$ & $\begin{array}{c}T_{\text {internal }} \\
\left({ }^{\circ} \mathrm{C}\right)\end{array}$ & $\begin{array}{c}I_{g} \\
\left(\mathrm{~W} / \mathrm{m}^{2}\right)\end{array}$ & $\begin{array}{c}I_{d} \\
\left(\mathrm{~W} / \mathrm{m}^{2}\right)\end{array}$ \\
\hline $11: 20$ & 40 & 82 & 980 & 784 \\
$11: 25$ & 50 & 85 & 980 & 784 \\
$11: 30$ & 57 & 77 & 980 & 784 \\
$11: 35$ & 66 & 86 & 977 & 781,6 \\
$11: 40$ & 57 & 76 & 960 & 768 \\
$11: 45$ & 80 & 69 & 940 & 752 \\
$11: 50$ & 84 & 75 & 920 & 736 \\
$11: 55$ & 85 & 72 & 880 & 704 \\
$12: 00$ & 88 & 82 & 880 & 704 \\
\hline AVERAGE & 83 & 74 & 880 & 704 \\
\hline
\end{tabular}

The maximum temperatures in the absorber surface and internal air of solar oven corresponding to $114^{\circ} \mathrm{C}$ and $105^{\circ}$ $\mathrm{C}$, respectively, were significant and suitable to provide the baking of foods. The average temperatures for these parameters during the test duration, at around $102.4^{\circ} \mathrm{C}$ and 94.6 C, respectively, are also suitable for obtaining the desired end. The average ambient temperature was $29.5^{\circ} \mathrm{C}$, the thermal sensation of $33.5^{\circ} \mathrm{C}$, average humidity of $60 \%$, the global solar radiation average of $966.6 \mathrm{~W} / \mathrm{m}^{2}$ and direct solar radiation average of $773.3 \mathrm{~W} / \mathrm{m}^{2}$.

Despite temperatures of the absorber surface and inside the oven being well below conventional gas oven with internal temperatures up to $250^{\circ} \mathrm{C}$, solar ovens previously fabricated and tested reached levels similar to those achieved by the solar oven in the study and enabled the baking of foods.

Tests with box type solar cookers have already shown their greater viability for baking food. Then broke for testing for baking of some foods whose results are shown below.

A cake was baked and the results of the measured parameters in this test are shown in Table 3. The complete baking of the cake 700 was obtained in 45 minutes. The test was started at 11:15 hours. After placing the cake mixture in shaped the absorber temperature was of $40^{\circ} \mathrm{C}$ and the internal of the oven of $82^{\circ} \mathrm{C}$. The environment temperature during the test was on average $30.5^{\circ} \mathrm{C}$, the thermal sensation $35.3^{\circ} \mathrm{C}$ and relative humidity of $60 \%$.

Despite temperatures inside and base are well below the levels achieved in a conventional oven gas, again evidenced the viability thermal furnace proposed for obtaining the cake, baked in 45 minutes, long enough near the time needed to make the same food in a conventional oven. This is explained by the combination of energetic contributions of the greenhouse effect and concentration that leads to a condition suitable for obtaining the foods baking. Solar conditions were ideal for the use of solar oven radiation global average around $940 \mathrm{~W} / \mathrm{m}^{2}$ and direct radiation around $750 \mathrm{~W} / \mathrm{m}^{2}$.

Other solar ovens tested had already baking time for the same cake found in the above mentioned experiment, similar to levels of radiation. It should be noted the cost-benefit study presented by the oven. Fig. 3 shows the cake baked in the oven proposed.

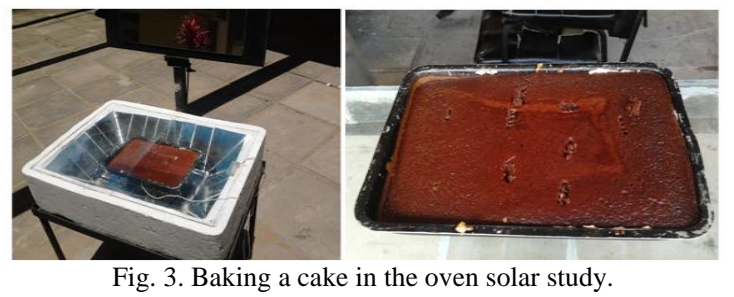

Another test conducted with the oven was baking a pizza. Table IV shows the results of the temperatures inside the oven and the absorber, global and direct solar radiation. The test began at 12:10 hours. The temperature before placing the pizza were $41^{\circ} \mathrm{C}$ for the shaped temperature and $80.0^{\circ} \mathrm{C}$ to the air temperature inside the oven. The environment average temperature was around $30.8^{\circ} \mathrm{C}$ during the test, the thermal sensation of $36.4^{\circ} \mathrm{C}$ and relative humidity of $60 \%$. The complete baking pizza happened in 15 minutes.

TABLE IV: TEST RESUlts FOR BAKING A PIZZA IN THE OVEN SOLAR PROPOSED

\begin{tabular}{ccccc}
\hline $\begin{array}{c}\text { Time } \\
(\text { hour })\end{array}$ & $\begin{array}{c}T_{\text {absorber }} \\
\left({ }^{\circ} \mathrm{C}\right)\end{array}$ & $\begin{array}{c}T_{\text {internal }} \\
\left({ }^{\circ} \mathrm{C}\right)\end{array}$ & $\begin{array}{c}I_{g} \\
\left(\mathrm{~W} / \mathrm{m}^{2}\right)\end{array}$ & $\begin{array}{c}I_{d} \\
\left(\mathrm{~W} / \mathrm{m}^{2}\right)\end{array}$ \\
\hline $12: 10$ & 41 & 80 & 970 & 776 \\
$12: 15$ & 51 & 84 & 980 & 784 \\
$12: 20$ & 60 & 86 & 990 & 792 \\
$12: 25$ & 62 & 88 & 1000 & 800 \\
\hline AVERAGE & 66 & 84,5 & 985 & 788 \\
\hline
\end{tabular}

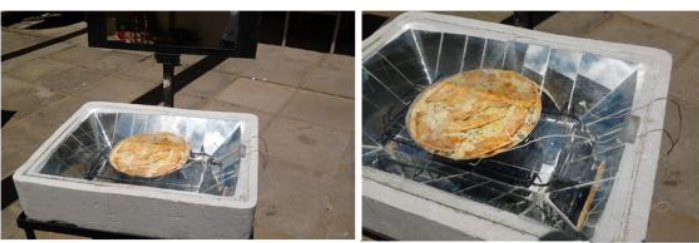

Fig. 4. Baking a pizza in the oven solar study.

The internal temperature of the oven and of absorber were below achieved with a conventional oven gas. However, considering that the time of baking a pizza in a conventional oven gas happens in about 10 minutes, the solar oven built was feasible to bake this food, as provided in attached fifteen minutes of baking the pizza. In relation to that food was the oven that had the best results of all tested already in LMHES. It should be noted the excellent weather conditions for this test. Fig. 4 shows the baking a pizza in the oven solar study.

A third test was performed in the oven baking of chicken fingers, five units, each with a mass of $100 \mathrm{~g}, 500 \mathrm{~g}$ total. Table $\mathrm{V}$ shows the results of the temperatures inside the oven and absorber shaped. The test began at 12:30 hours. The temperatures of breaded before baking were $46^{\circ} \mathrm{C}$ for the absorber temperature and $71^{\circ} \mathrm{C}$ to the air temperature inside the oven. The average temperature was around $30.3^{\circ}$ 
$\mathrm{C}$ during the test, the thermal sensation of $35.3^{\circ} \mathrm{C}$ and relative humidity of $60 \%$. The complete baking the breaded happened in twenty-five minutes.

TABLE V: TEST RESULTS FOR BAKING FINGERS CHICKEN IN THE OVEN PROPOSED

\begin{tabular}{ccccc}
\multicolumn{5}{c}{ PROPOSED } \\
$\begin{array}{c}\text { Time } \\
\text { (hour) }\end{array}$ & $\begin{array}{c}T_{\text {absorber }}\left({ }^{\circ} \mathrm{C}\right) \\
12: 30\end{array}$ & $\begin{array}{c}T_{\text {internal }} \\
\left({ }^{\circ} \mathrm{C}\right)\end{array}$ & $\begin{array}{c}I_{g} \\
\left(\mathrm{~W} / \mathrm{m}^{2}\right)\end{array}$ & $\begin{array}{c}I_{d} \\
\left(\mathrm{~W} / \mathrm{m}^{2}\right)\end{array}$ \\
\hline $12: 35$ & 46 & 71 & 1009 & 807,2 \\
$12: 40$ & 56 & 73 & 990 & 792 \\
$12: 45$ & 61 & 75 & 980 & 784 \\
$12: 55$ & 65 & 77 & 970 & 776 \\
\hline AVERAGE & 70 & 79 & 960 & 768 \\
\hline
\end{tabular}

The internal temperature of solar oven and the absorber were once again well below achieved with a conventional oven gas. However, considering that the time of baking the batter in a conventional oven gas happens in about 15 minutes, the solar oven studied was feasible to bake this food, especially for its low cost. Solar radiation levels was of great magnitude, reaching maximum values for global and direct solar radiation above $1000 \mathrm{e} 800 \mathrm{~W} / \mathrm{m}^{2}$, respectively. Fig. 5 presents the breaded in the solar oven baking proposed.
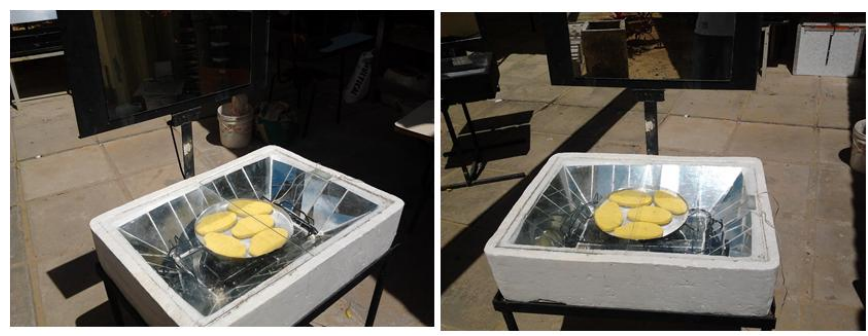

Fig. 5. Breaded chicken baking in the oven solar study.

TABLE VII: AVERAGE PARAMETERS MEASURED IN THE TESTS CHOSEN FOR BAKING FOOD.

\begin{tabular}{|c|c|c|c|c|c|c|c|c|}
\hline FOOD & $\begin{array}{l}\text { Mass } \\
(\mathrm{g})\end{array}$ & $\begin{array}{l}\text { Baking time } \\
\text { (min) }\end{array}$ & Baking time others ovens (min) & $\begin{array}{l}\text { Baking time gas oven } \\
\text { (min) }\end{array}$ & $\begin{array}{l}T_{\text {int }} \\
\left({ }^{\circ} \mathrm{C}\right)\end{array}$ & $\begin{array}{l}T_{a b s} \\
\left({ }^{\circ} \mathrm{C}\right)\end{array}$ & $\begin{array}{c}I_{G} \\
\left({ }^{\circ} \mathrm{C}\right)\end{array}$ & $\begin{array}{c}I_{D} \\
\left({ }^{\circ} \mathrm{C}\right)\end{array}$ \\
\hline PIZZA & 460 & 20 & 15 a 30 & 10 a 15 & 78.9 & 90.6 & 841.4 & 673.1 \\
\hline CHEESE BREAD & 400 & 80 & 60 a 80 & 30 a 40 & 85.0 & 84.7 & 773.0 & 618.4 \\
\hline NUGGETS & 300 & 30 & 25 a 35 & 10 a 20 & 76.7 & 83.7 & 921.0 & 736.8 \\
\hline CAKE & 700 & 50 & 60 a 80 & 40 a 45 & 90.4 & 91.4 & 928.0 & 742.4 \\
\hline KIBES & 500 & 60 & 50 a 80 & 30 a 40 & 74.0 & 83.6 & 1006.0 & 804.8 \\
\hline LASAGNA & 650 & 60 & 60 a 80 & 40 a 45 & 66.7 & 87.0 & 907.0 & 725.6 \\
\hline
\end{tabular}

For the diagnosis of thermal loss from the oven temperatures were measured from their outer surfaces. Fig. 6 shows the mean values of temperatures measured during the test without load at 11 hours.

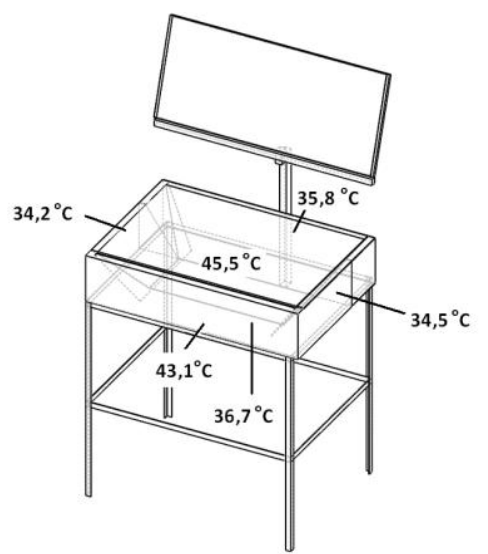

Fig. 7. Temperatures on the external surfaces of the oven.

Levels of external temperature of the solar oven studied demonstrated its low thermal loss, as evidenced by low time for baking foods tested, competitive with solar ovens solar pointed out the literature for baking foods and even conventional ovens with gas.
Table VI presents the average parameters of the oven for all foods tested.

TABLE VI : AVERAgE PARAMETERS MEASURED IN THE TESTS FOR

\begin{tabular}{ccccccc}
\multicolumn{7}{c}{ BAKING FOOD } \\
\hline FOOD & $\begin{array}{c}\text { Mass } \\
(\mathrm{g})\end{array}$ & $\begin{array}{c}\text { Baking } \\
\text { time } \\
(\mathrm{min})\end{array}$ & $\begin{array}{c}T_{a b s} \\
\left({ }^{\circ} \mathrm{C}\right)\end{array}$ & $\begin{array}{c}T_{\text {int }} \\
\left({ }^{\circ} \mathrm{C}\right)\end{array}$ & $\begin{array}{c}I_{g} \\
\left({ }^{\circ} \mathrm{C}\right)\end{array}$ & $\begin{array}{c}I_{d} \\
\left({ }^{\circ} \mathrm{C}\right)\end{array}$ \\
\hline PIZZA & 460 & 15 & 66 & 84,5 & 985 & 788 \\
CAKE & 700 & 45 & 69 & 77,8 & 937,7 & 750,16 \\
STEAKS & 500 & 25 & 59,6 & 75 & 981,8 & 785,4 \\
\hline
\end{tabular}

The baking time for the oven studied obtained are inferior to all other versions already tested in LMHES / UFRN. The mirroring procedure with profiles stepped produced a higher concentration of rays inside the oven and being absorbed by the absorber shaped led to a higher rate of heating of food. It's baking time to solar conditions excellent were comparable to those obtained for the conventional oven gas, mainly for the cake. Table VII presents the cooking time for some ovens and tested for the conventional oven gas and its values confirm the performance of the solar oven stud mainly by two factors greater concentration of radiation in the bottom of the absorber and a higher thermal insulation by your box is made of a material of very good thermal insulation. 


\section{CONCLUSIONS AND SUGGeSTIONS}

1) The proposed solar oven itself proposed feasible to bake food from 9:00 am to 2:00 pm under solar conditions good;

2) The solar oven has become competitive with conventional gas oven;

3) The solar oven was studied that had easy assembly and manufacturing processes, manufacturing technology and can be passed on to needy communities;

4) The proposed solar oven has a good cost-benefit ratio for its low manufacturing cost;

5) The solar oven studied showed the best results for the baking of food among all solar ovens manufactured and studied in LMHES/UFRN;

6) The cooking times of foods tested are comparable with those presented in the literature for solar cooking food;

7) All food baked in the oven had proposed solar cooking times competitive with conventional oven and gas were lower than the time indicated by the literature for solar cooking food. The proposed solar oven was more competitive with conventional gas oven for baking a cake;

8) It is important to have another conventional source for cooking food to replace the proposed solar cooker on days with insufficient solar conditions for its use.

\section{REFERENCES}

[1] J. W. Gomes, Construction and Performance Analysis of a Oven / Solar Cooker Type Package Alternative Built from a Tire Scrap, Dissertação (Mestrado em Engenharia Mecânica) Pós-graduate Program in Mechanical Engineering, Federal University of Rio Grande do Norte, Natal, RN, 2009.

[2] National Energy Balance. (2012). [Online]. Available: https://ben.epe.gov.br/

[3] Araújo et al., "Use of solar cooker type box for drying foods in lowincome community," I $I^{a}$ Brazilian Solar Energy Congress, Fortaleza, CE, 2007.

[4] A. V. Melo, Performance of a Solar Cooker Enclosure Type Built From a Scrap of a Conventional Gas Stove, Dissertação (Mestrado em Engenharia Mecânica) Programa de Pós-Graduação em Engenharia Mecânica, Federal University do Rio Grande do Norte, Natal, RN, 2008.

[5] A. M. Bezerra, Thermal Applications of Solar Energy, João Pessoa: University Publishing - UFPB, 2002.

[6] L. G. M. Souza et al., Solar Oven Made from a Freezer Scrap, VII CONEM - National Congress of Mechanical Engineering, Natal-RN, 2012.

[7] L. G. M. Souza et al., "Solar cooking built in composite material," in Proc. 20th COBEM - International Congress of Mechanical Engineering, Gramado-RS, 2009.

[8] L. G. M. Souza et al., Low Cost Solar Oven Made with Blocks made of Composite Material, VI CONEM - National Congress of Mechanical Engineering, Salvador,Ba, 2008.

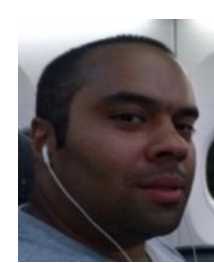

Jailton Weber Gomes worked as a professor of the Federal Institute of Bahia Camaçari campus since 2007. Prof. Me. Jailton Weber Gomes is teaching industrial automation electrical cources. Currently, he is a doctoral student in mechanical engineering in the area of concentration materials sciences at the Federal University of Rio Grande do Norte.

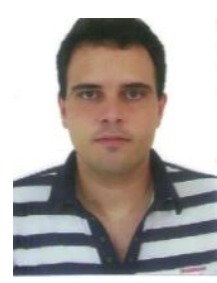

Natanaeyfle Randemberg Gomes dos Santos worked as a professor of Mauricio de Nassau, Teaches disciplines solid mechanics and metrology. He received his $\mathrm{PhD}$ in mechanical engineering from the Federal University of Rio Grande do Norte in 2015.

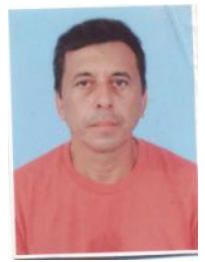

Luiz Guilherme Meira de Souza worked as a titular professor at the Department of Mechanical Engineering of UFRN. He is a doctor of engineering, professor for 34 years of the Departments of Mechanical Engineering and Graduate in Mechanical Engineering and currently coordinator of the Graduate Program in Mechanical Engineering UFRN.

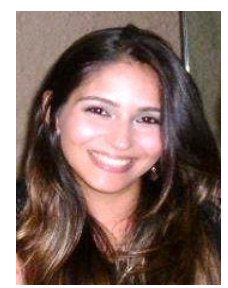

Larissa Caroline Fernandes Costa is a master's student in the Graduate Program in mechanical engineering and graduated in materials engineering at the Federal University of Rio Grande do Norte.

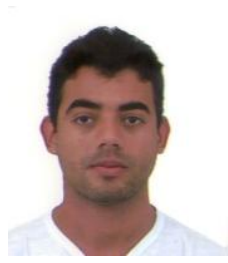

Luiz Guilherme Vieira de Souza Meira is a master of mechanical engineering, substitute professor of the Department of Mechanical Engineering at the Federal University of Rio Grande do Norte, $\mathrm{PhD}$ student in Mechanical Engineering UFRN.

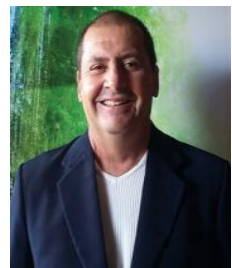

Carlos Roberto Rocha da Silva worked as a professor of mathematics of the Federal Institute of Bahia (IFBA), Specialist Mathematics (UESB), He received his master in mechanical engineering (UFRN) $\mathrm{PhD}$ in mechanical engineering from the Federal University of Rio Grande do Norte . 